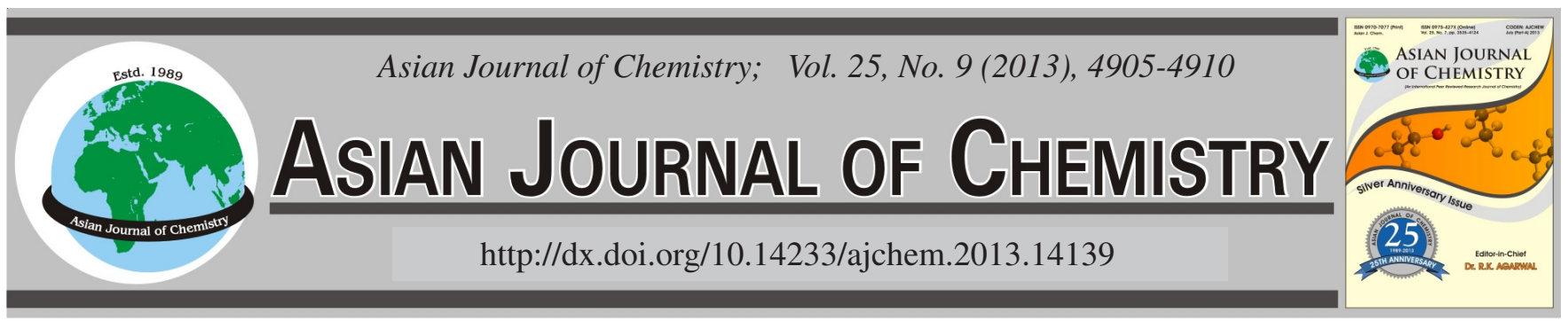

\title{
Analysis of Molin River Water Chemistry in the Ordos Basin, China
}

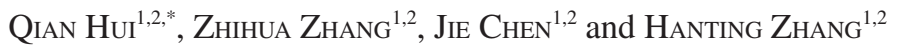

${ }^{1}$ School of Environmental Science and Engineering, Chang'an University, No. 126 Yanta Road, Xi'an 710054, Shaanxi Province, P.R. China ${ }^{2}$ Key Laboratory of Subsurface Hydrology and Ecology in Arid Areas, Ministry of Education, No. 126 Yanta Road, Xi'an 710054, Shaanxi Province, P.R. China

*Corresponding author: E-mail: qianhui@chd.edu.cn

(Received: 30 May 2012;

Accepted: 8 March 2013)

AJC-13100

Molin river is located in the arid region of Inner Mongolia, China. To study the changes of water composition along the river, 19 river water and groundwater samples were collected for chemical and isotopic analysis. The TDS, major ion concentrations, chemical type, as well as $\delta^{18} \mathrm{O}$ and $\delta^{2} \mathrm{H}$ of river water were compared. Equilibrium speciation calculation was employed to calculate the saturation indices of minerals. Mass balance model was used to analyze the mechanisms of the changes of river water composition. Results showed gypsum dissolution, calcite precipitation, ion exchange, mixing processes and evaporation of river water all play important roles in the formation of river water composition.

Key Words: Molin river, Water chemistry, Stable isotopes, Formation mechanisms, Ordos basin.

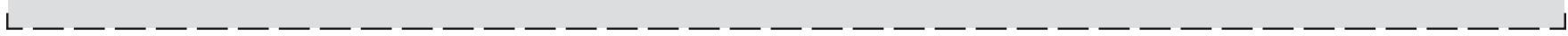

\section{INTRODUCTION}

There is a worldwide deterioration of water quality due to natural processes and human activities ${ }^{1}$. The major element composition of river water can reveal the nature and patterns of geochemical evolution of the river and the linkage between natural processes and anthropogenic processes. As a result, a lot of geochemical studies in the world have been conducted for determining the mechanisms controlling river water chemistry ${ }^{2-17}$.

Molin river is a small continental river in the northwest corner of Ordos basin. The length of the river is $81 \mathrm{~km}$ and its drainage area is $5220 \mathrm{~km}^{2}$. The runoff of the Molin river mainly comes from the local groundwater. So the hydrogeological setting of the river basin is vital to the analysis of the river water. This paper investigated the changes of water chemistry and isotope compositions of the Molin river and the mechanisms behind these changes. The focuses are mainly on the quantitative modeling of the changes on the basis of the hydrogeology. This is of great significance to the understanding of the relationship between surface water and groundwater. It is also helpful for the reasonable assessment of the groundwater resources in Ordos basin.

\section{EXPERIMENTAL}

Hydrogeological setting: Molin river drainage basin belongs to the continental monsoon climate zone with cold and long winter, hot and short summer, less but concentrated rainfall and strong evaporation. The annual precipitation is 188-282 mm and mainly concentrated in June to August which accounts for about 57-66 \% of the total. The annual evaporation intensity is between 2000 and $3450 \mathrm{~mm}$.

In recent years, China Geological Survey has implemented a project called "Groundwater Exploration in the Ordos basin", much research work thereupon has been done in the region ${ }^{18-24}$. With these, it is possible to get an insight of the hydrogeology of the Molin river basin. According to the lithology and geological age of the strata, the aquifers in the Molin river basin can be divided into three groups ${ }^{21,23}$. From the top down, they are Luohandong group, Huanhe group and Luohe group, respectively. There is no continuous aquitard between these aquifers $^{24}$.

The Luohandong group distributes mainly in the northern part of the studied area (Fig. 1). It is composed of a set of continental clastic rocks of early Cretaceous age. The thickness of the formation is $200-562 \mathrm{~m}$. The lithology is primarily sandstone, coarse sandstone interbedded by fine sandstone, conglomerate and sandy gravel. The Huanhe group lies beneath the Luohandong group and exists in the whole studied area. The thickness of the group is 281-768 m. The lithology is primarily conglomerate, sandy gravel, sandstone and becomes finer downward. The Luohe group is overlain by the Huanhe group in the whole region. The lithology of the group is mainly continental clastic rock of sandstone, mudstone, conglomerate and sandy gravel formed in the early Cretaceous period. The 
TABLE-1

CHEMICAL ANALYSIS RESULTS OF THE WATER SAMPLES (mg L ${ }^{-1}$ )

\begin{tabular}{|c|c|c|c|c|c|c|c|c|c|c|c|c|c|}
\hline No. & $\mathrm{Y}(\mathrm{m})$ & $\mathrm{X}(\mathrm{m})$ & TDS & $\mathrm{pH}$ & $\mathrm{Na}^{+}+\mathrm{K}^{+}$ & $\mathrm{Ca}^{2+}$ & $\mathrm{Mg}^{2+}$ & $\mathrm{Cl}^{-}$ & $\mathrm{SO}_{4}{ }^{2-}$ & $\mathrm{HCO}_{3}^{-}$ & $\mathrm{SI}_{\text {calcite }}$ & $\mathrm{SI}_{\text {dolomite }}$ & $\mathrm{SI}_{\text {gypsum }}$ \\
\hline G1 & 18751624.00 & 4421525.00 & 555.25 & 7.65 & 97.46 & 60.12 & 23.70 & 140.04 & 75.41 & 202.58 & -0.002 & -0.371 & -1.782 \\
\hline G2 & 18742131.77 & 4424195.58 & 364.90 & 8.00 & 114.60 & 11.60 & 10.20 & 36.20 & 85.50 & 213.60 & -0.297 & -0.617 & -2.359 \\
\hline G3 & 18747449.58 & 4426373.59 & 336.92 & 8.10 & 111.55 & 9.64 & 4.95 & 369.88 & 59.56 & 208.68 & -0.27 & -0.795 & -2.567 \\
\hline G4 & 18758264.32 & 4429247.00 & 316.80 & 7.70 & 80.80 & 21.34 & 13.07 & 53.75 & 52.35 & 158.47 & -0.446 & -1.069 & -2.289 \\
\hline G5 & 18749450.00 & 4429950.00 & 862.39 & 8.54 & 258.05 & 35.67 & 26.38 & 138.27 & 139.29 & 507.21 & 0.995 & 1.898 & -1.835 \\
\hline M1 & 18749362.70 & 4430186.07 & 948.35 & 8.30 & 310.00 & 32.10 & 24.10 & 177.20 & 135.00 & 518.60 & 0.723 & 1.359 & -1.897 \\
\hline G6 & 18747596.00 & 4433221.00 & 711.47 & 8.35 & 241.91 & 18.04 & 13.67 & 130.31 & 163.35 & 273.22 & 0.282 & 0.479 & -1.998 \\
\hline G7 & 187475 & 44335 & 737.35 & 8.61 & 231.84 & 25.05 & 18.60 & 132.95 & 133.53 & 365.70 & 0.794 & 1.497 & -1.964 \\
\hline M2 & 187470 & 44359 & 653.66 & 8.30 & 00 & 32.10 & 10.70 & 120.50 & 93.70 & 341.60 & 0.594 & 0.748 & -1.971 \\
\hline G8 & 187520 & 4437797.27 & 276.50 & 7.90 & 84.76 & 10.08 & 8.22 & 29.50 & 60.04 & 167.80 & -0.538 & -1.131 & -2.53 \\
\hline G9 & 18743736.66 & 4438520.24 & 1457.59 & 7.70 & 442.50 & 78.76 & 8.27 & 326.20 & 534.13 & 135.46 & -0.148 & -1.243 & -1.01 \\
\hline G10 & 18751979.67 & 4440040.12 & 984.16 & 7.70 & 308.20 & 41.57 & 19.69 & 185.69 & 184.44 & 489.13 & 0.199 & 0.109 & -1.651 \\
\hline G11 & 18740675.00 & 4440053.00 & 6347.38 & 7.20 & 1537.58 & 434.67 & 26.79 & 705.48 & 3607.03 & 43.57 & -0.739 & -2.663 & 0.082 \\
\hline G12 & 18742363.12 & 4440088.52 & 1072.60 & 7.49 & 372.46 & 15.83 & 11.98 & 231.33 & 247.37 & 372.82 & -0.552 & -1.192 & -1.941 \\
\hline G13 & 18740159.53 & 4440407.36 & 1260.22 & 8.00 & 429.50 & 21.24 & 5.11 & 335.07 & 382.34 & 173.91 & -0.265 & -1.117 & -1.662 \\
\hline G14 & 18726010.00 & 4441513.00 & 2819.32 & 7.90 & 551.20 & 333.87 & 31.48 & 416.57 & 1404.94 & 103.73 & 0.431 & -0.133 & -0.195 \\
\hline M3 & 18743025.80 & 4445491.02 & 634.26 & 8.30 & 200.00 & 18.00 & 4.00 & 102.80 & 140.70 & 265.40 & 0.241 & -0.138 & -2.024 \\
\hline G15 & 18738157.93 & 4445661.94 & 2472.19 & 8.20 & 779.18 & 44.01 & 52.22 & 508.08 & 806.90 & 563.60 & 0.636 & 1.379 & -1.23 \\
\hline
\end{tabular}

maximum thickness of the group in the region is more than $300 \mathrm{~m}$.

In the Molin river basin, the recharge of groundwater is mainly from the precipitation infiltration. The groundwater in the Luohandong group generally flows to the Molin river and becomes the main source of the river runoff. On the whole, the groundwater in the aquifers beneath the Luohandong group flows from south to north. The effects of Molin river to their flow directions are not as obvious as that of Luohandong group. Apart from discharges to the Molin river, artificial exploitation and discharges to the outside of north border are the other two forms of the groundwater discharge in the region.

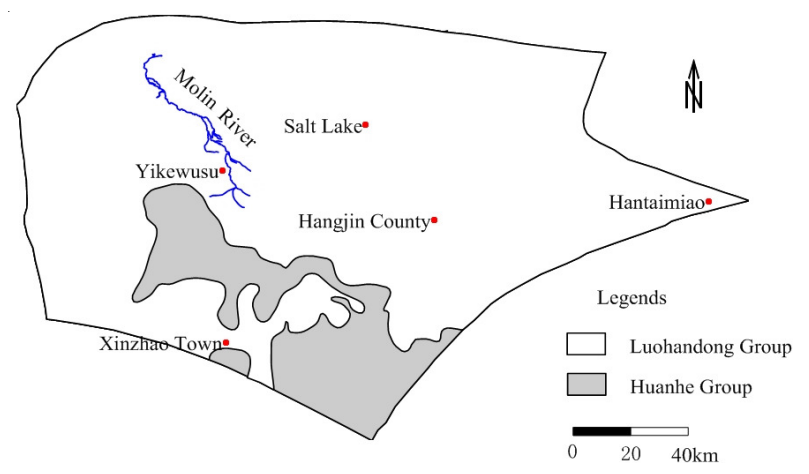

Fig. 1. Distribution of aquifers in the Molin river basin

\section{RESULTS AND DISCUSSION}

Changes of the river water composition: In this study, 3 samples of river water and 15 samples of groundwater were collected on September 10-11, 2004. The three river water samples were collected in the upper, middle and lower reaches of the river respectively. Table- 1 lists the chemical analysis results of the samples. In the table, M1, M2 and M3 are river waters, the others are groundwater samples. $\mathrm{Y}$ and $\mathrm{X}$ are coordinates of sampling points in the Gaussian coordinate system. $\mathrm{SI}_{\mathrm{cal}}, \mathrm{SI}_{\mathrm{gyp}}$ and $\mathrm{SI}_{\mathrm{dol}}$ are the saturation indices of calcite, gypsum and dolomite, respectively. The water samples in Table- 1 are put along the flow direction of the river. For example, the water samples before M1 in Table-1 are in the upper part of M1 and the water samples between M1 and M2 are in the upper part of M2 and the lower part of M1.

Fig. 2 shows the changes of TDS and concentrations of major ions in the river water along its flow direction. It is clear from the figure that all the major ion concentrations have a decreasing trend downstream except $\mathrm{K}^{+}$and $\mathrm{SO}_{4}{ }^{2-}$. Table-2 lists percentages of milliequivalent concentrations (PMEC) of cations and anions in the Molin river water, respectively. It can be seen that the dominant cation is $\mathrm{Na}^{+}$with PMEC larger than $78 \%$ and the PMECs of other cations are less than $14 \%$. The dominant anion is $\mathrm{HCO}_{3}{ }^{-}$with $\mathrm{PMEC}$ larger than $42 \%$, $\mathrm{Cl}^{-}$and $\mathrm{SO}_{4}{ }^{2-}$ also take non-ignorable proportions. It should be noted that the PMEC of $\mathrm{SO}_{4}{ }^{2-}$ increases steadily downstream, which markedly contrast the fact in Fig. 3 that the concentration of $\mathrm{SO}_{4}{ }^{2-}$ drop first and then rise along the flow direction. This determines the river water being $\mathrm{HCO}_{3} \cdot \mathrm{Cl}-\mathrm{Na}$ type in the upper and middle reaches and changing into $\mathrm{HCO}_{3} \cdot \mathrm{SO}_{4} \cdot \mathrm{Cl}-\mathrm{Na}$ type in the lower reaches of the river.

TABLE-2

PERCENTAGES OF MILLIEQUIVALENT CONCENTRATIONS OF IONS IN THE MOLIN RIVER WATER (\%)

\begin{tabular}{lcccccccc}
\hline No. & $\mathrm{K}^{+}$ & $\mathrm{Na}^{+}$ & $\mathrm{Ca}^{2+}$ & $\mathrm{Mg}^{2+}$ & $\mathrm{Cl}^{-}$ & $\mathrm{SO}_{4}^{2-}$ & $\mathrm{HCO}_{3}^{-}$ & $\mathrm{CO}_{3}^{2-}$ \\
\hline M1 & 0.54 & 78.57 & 9.33 & 11.55 & 30.46 & 17.13 & 51.20 & 1.22 \\
M2 & 0.41 & 78.31 & 13.73 & 7.55 & 30.76 & 17.65 & 49.78 & 1.81 \\
M3 & 4.55 & 83.65 & 8.64 & 3.16 & 28.34 & 28.64 & 42.04 & 0.98 \\
\hline
\end{tabular}

Fig. 3 shows the changes of saturation indices of calcite, dolomite and gypsum along the Molin river. It can be seen that the $\mathrm{SI}_{\mathrm{gypsum}}$ of all the 3 river water samples are less than 0 , so the river waters are unsaturated with respect to gypsum. Since $\mathrm{SI}_{\text {calcite }}$ are all larger than 0 for all the river water samples, so the river waters are oversaturated with respect calcite. Comparatively, the dolomite is oversaturated in M1 and M2 and unsaturated in M3.

Isotopic characteristics: In this study, 3 river water samples (M1-3) were collected for stable hydrogen and oxygen isotope analysis and another 15 isotopic analysis results of groundwater, river water and lake water in the Molin river basin by other researchers were referred. Fig. 4 is the plot of 


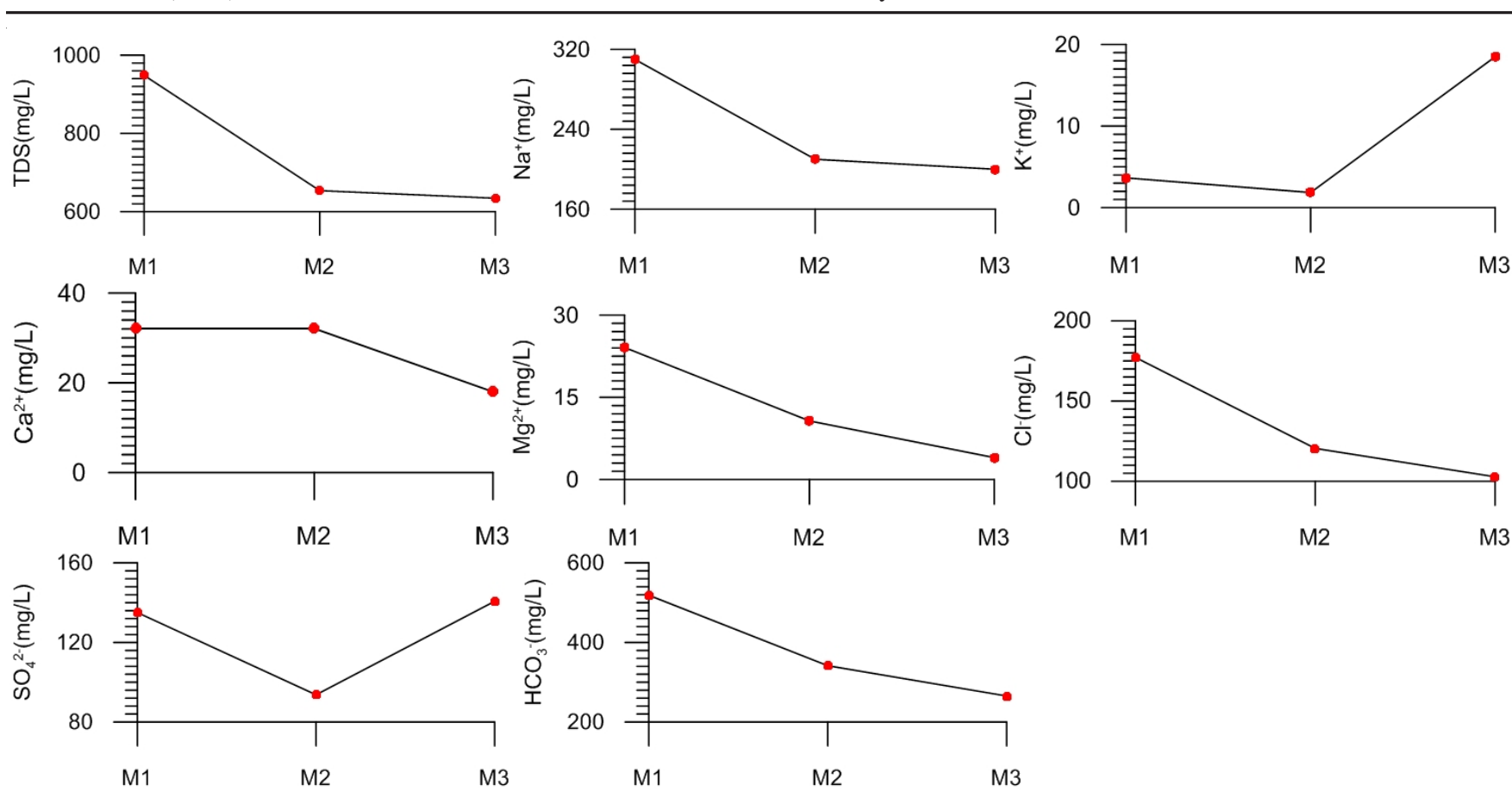

Fig. 2. Changes of major ion concentrations in the river water along the flow direction

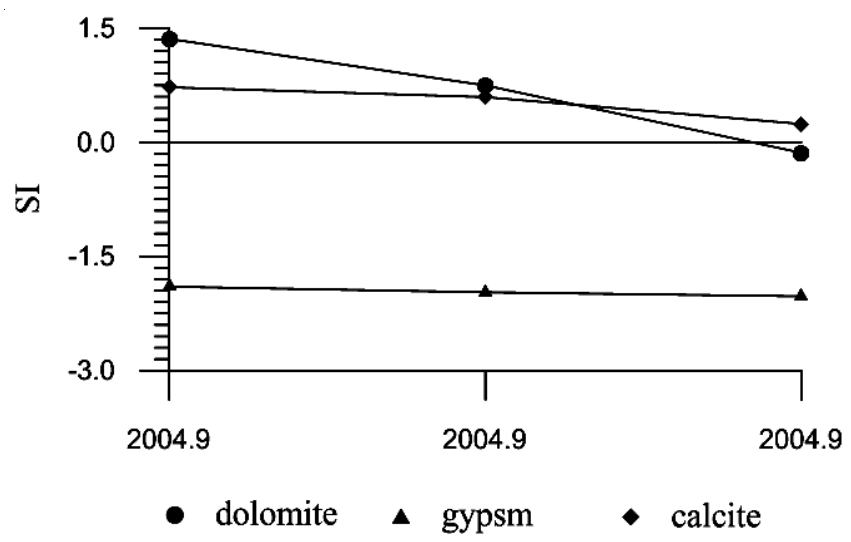

Fig. 3. Changes of saturation indices of minerals along the Molin river

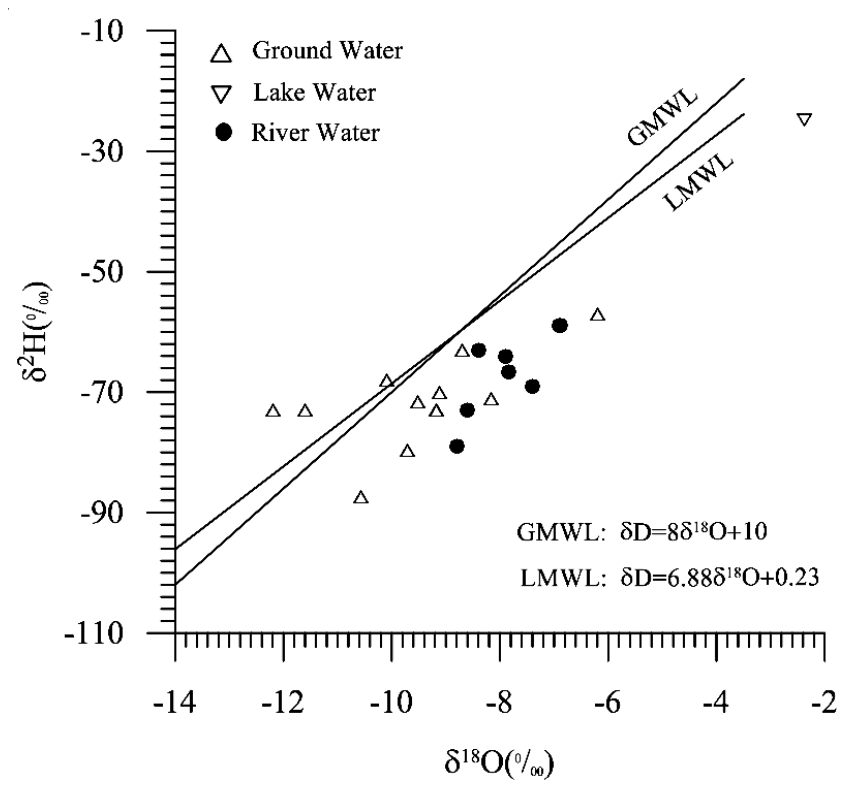

Fig. 4. Plot of $\delta^{18} \mathrm{O}$ versus $\delta^{2} \mathrm{H}$ values from streams, groundwater and lake waters $\delta^{18} \mathrm{O}$ versus $\delta^{2} \mathrm{H}$ for river water, groundwater and lake waters, the Global Meteoric Water Line (GMWL, Craig, 1961) ${ }^{25}$ and the Local Meteoric Water Line (LMWL) in the Ordos basin are also compared. It can be seen from Fig. 6 that the isotopic composition of the Molin river is affected by evaporation, which leads to the concentration of the stable isotopes of river water being higher than that of groundwater. The mean values of $\delta^{18} \mathrm{O}$ and $\delta^{2} \mathrm{H}$ for the river water are $-7.71 \%$ and $-64.49 \%$ o respectively, contrasting the values of $-9.52 \%$ and $-71.64 \%$ o for the groundwater. In Fig. 5, the $\delta^{18} \mathrm{O}$ and $\delta^{2} \mathrm{H}$ are plotted along flow direction of the river. Obviously, the stable isotopic concentrations increase from $\mathrm{M} 1$ to $\mathrm{M} 2$ and decrease from M2 to $\mathrm{M} 3$. The $\delta^{18} \mathrm{O}$ and $\delta^{2} \mathrm{H}$ have maximums corresponding to $\mathrm{M} 2$.

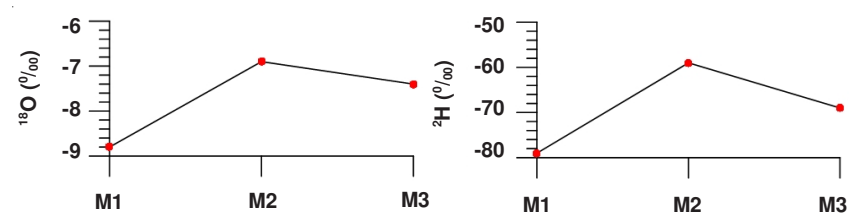

Fig. 5. Changes of $\delta^{18} \mathrm{O}$ and $\delta^{2} \mathrm{H}$ along the Molin river

\section{Formation of the chemical composition of the river water}

River water at M1: M1 is located in the upper reaches of the Molin river. Five groundwater samples were collected in the upper part of M1 which include 4 samples taken from Luohandong group aquifer and 1 sample taken from Huanhe group aquifer. It can be seen from Table-1 that the TDS of the ground water samples in the upper part of M1 are all less than that of M1. So the water composition at M1 can't be formed by the simple mixing of these ground waters.

The isotope analysis results can be used to assess the effect of evaporation on the formation of river water chemistry at $\mathrm{M} 1^{26-28}$. The $\delta^{18} \mathrm{O}$ and $\delta^{2} \mathrm{H}$ of $\mathrm{M} 1$ are $-8.8 \%$ and $-79 \%$ respectively. The mean values of $\delta^{18} \mathrm{O}$ and $\delta^{2} \mathrm{H}$ for ground water in the upper part of M1 are $-9.52 \%$ and $-71.64 \%$ respectively. 
Using the data of $\delta^{18} \mathrm{O}$ and the method of Rayleigh equilibrium fractionation equation, the calculated evaporation proportion at $\mathrm{M} 1$ is $7.66 \%$ and there is no evaporation if $\delta^{2} \mathrm{H}$ is used. It is clear that the evaporation may have some contribution to the formation of river water chemistry at M1, but it doesn't play a primary role.

So the chemical composition of river water at M1 is mainly formed by the dissolution or precipitation of minerals and the ion exchange reaction. Since most of the groundwater samples are unsaturated with respect to gypsum, calcite, dolomite and salt, so the dissolution of these minerals by the following reactions plays important roles in the formation of river water composition.

$$
\begin{gathered}
\mathrm{CaSO}_{4}(\text { gypsum })=\mathrm{SO}_{4}{ }^{2-}+\mathrm{Ca}^{2+} \\
\mathrm{CaCO}_{3}(\text { calcite })+\mathrm{CO}_{2}+\mathrm{H}_{2} \mathrm{O}=2 \mathrm{HCO}_{3}{ }^{-}+\mathrm{Ca}^{2+}
\end{gathered}
$$

$\mathrm{CaMg}\left(\mathrm{CO}_{3}\right)_{2}$ (dolomite) $+2 \mathrm{CO}_{2}+2 \mathrm{H}_{2} \mathrm{O}=4 \mathrm{HCO}_{3}{ }^{-}+\mathrm{Ca}^{2+}+\mathrm{Mg}^{2+}$ (3)

$$
\mathrm{NaCl} \text { (salt) }=\mathrm{Cl}^{-}+\mathrm{Na}^{+}
$$

At the same time, the $\mathrm{Ca}^{2+}$ formed by the above reactions can exchange with the $\mathrm{Na}^{+}$in the aquifer by the following ion exchange reaction:

$$
\mathrm{Ca}^{2+}+2 \mathrm{NaX}=2 \mathrm{Na}^{+}+\mathrm{CaX}_{2}
$$

Assuming the river water chemistry at M1 is formed on the basis of groundwater G1-G4 and their mean values, the mass transfer during the reaction processes can be calculated by the mass balance model. The results (Table- 3 ) show the dissolution of calcite [reaction (2)] and the ion exchange [reaction (5)] play important roles in the formation of river water composition at M1. This is in accordance with the characteristics of water chemistry at M1 and the specific settings in the upper reaches of the Molin river. The $\mathrm{pH}$ value of river water at M1 is evidently higher than that of the groundwater in its upper reaches, the cause of this is the dissolution of calcite which will lead to the increase of the $\mathrm{pH}$ value of water. Besides, the upper reaches are in the source area of the Molin river, and there are vast swamps there. Under such conditions, the occurrence of the above reactions is natural.

Changes between M1 and M2: The most important feature of $\mathrm{M} 2$ is its $\delta^{18} \mathrm{O}$ and $\delta^{2} \mathrm{H}$ are the highest among M1-M3

TABLE-3

CALCULATED MASS TRANSFERS DURING PROCESSES FORMING THE CHEMISTRY OF M1 (mmol L-1)

\begin{tabular}{cccccc}
\hline $\begin{array}{c}\text { Water } \\
\text { samples }\end{array}$ & $\begin{array}{c}\text { Reaction } \\
(1)\end{array}$ & $\begin{array}{c}\text { Reaction } \\
(2)\end{array}$ & $\begin{array}{c}\text { Reaction } \\
(3)\end{array}$ & $\begin{array}{c}\text { Reaction } \\
(4)\end{array}$ & $\begin{array}{c}\text { Reaction } \\
(5)\end{array}$ \\
\hline G1 & 0.62 & 5.18 & 0.02 & 1.06 & 4.09 \\
G2 & 0.52 & 5.00 & 0.58 & 4.03 & 2.24 \\
G3 & 0.79 & 5.08 & 0.80 & 4.01 & 2.39 \\
G4 & 0.86 & 5.90 & 0.46 & 3.53 & 3.29 \\
Average & 0.70 & 5.29 & 0.46 & 3.16 & 2.97 \\
\hline
\end{tabular}

(Fig. 5). This is because a reservoir was built at M2, the extensive evaporation on the surface of the reservoir precisely explains the enrichment of $\delta^{18} \mathrm{O}$ and $\delta^{2} \mathrm{H}$. The evaporation proportion of river water at M2 can be estimated using the isotope analysis results. Based on the mean values of $\delta^{18} \mathrm{O}$ and $\delta^{2} \mathrm{H}$ of groundwater between M1 and M2, the calculated evaporation proportions are $25.15 \%$ and $17.82 \%$ respectively. Based on the mean values of $\delta^{18} \mathrm{O}$ and $\delta^{2} \mathrm{H}$ of river water at $\mathrm{M} 1$, the calculated evaporation proportions are $18.94 \%$ and $26.7 \%$ respectively. Obviously, the evaporation proportion of river water at M2 is around $20 \%$ compared with its feeding water. So the evaporation can't be ignored in the formation processes of river water chemistry at M2.

In order to study the effects of mixing on the formation of river water composition at M2, the major ion concentrations of the water samples in the upper reaches of M2 are plotted versus the TDS (Fig. 6), the water composition of M1 after 20 $\%$ evaporation (M1e) is also plotted. The figure shows that the river water composition at $\mathrm{M} 2$ can be formed by the simple mixing of water samples G3, G4 with Mle. Based on the mass balance of $\mathrm{Cl}^{-}$, the mixing proportion and the composition of the mixture can be calculated. The results are listed in Table-4. In the Table-4, G3-M1e, G4-M1e and average-M1e are the mixtures of samples G3, G4 and their averages with M1e, respectively.

Table-4 shows that when $54.71 \%$ of G3 is mixed with $45.29 \%$ of Mle, or $60.21 \%$ of G4 is mixed with $39.79 \%$ of Mle, or $57.33 \%$ of the averages of G3 and G4 is mixed with $42.67 \%$ of Mle, the mixture can generally reappear the river water composition at M2. The mixture of G4-Mle is nearly the same as the river water composition of M2. Considering G3 was collected from Huanhe formation and G4 was collected from Luohandong formation and the Molin river distributes nearly all in Luohandong formation areas, we concluded the river water chemistry at M2 is mainly formed by the mixing of G4 with Mle.

Changes between M2 and M3: The TDS of the river water decreases to some extent from M2 to M3. The possible reasons are: (1) the mixing of M2 with the local groundwater, (2) the dilution by rain, as it was raining when the sample M3 was collected on September 11, 2004. In the sight of the chemical analysis results of groundwater between M2 and M3, there is no possibility for the first circumstance to occur. Since the TDS of almost all the groundwater samples between M2 and M3 are larger than that of M2.

The decreases of TDS, $\delta^{18} \mathrm{O}$ and $\delta \mathrm{D}$ of river water from M2 to M3 can be easily explained by the dilution of rain. Yet

\begin{tabular}{|c|c|c|c|c|c|c|c|}
\hline Number (mixing ration) & TDS & $\mathrm{Na}^{+}+\mathrm{K}^{+}$ & $\mathrm{Ca}^{2+}$ & $\mathrm{Mg}^{2+}$ & $\mathrm{Cl}^{-}$ & $\mathrm{SO}_{4}^{2-}$ & $\mathrm{HCO}_{3}^{-}$ \\
\hline G3 & 326.92 & 111.55 & 9.64 & 4.95 & 36.88 & 59.56 & 208.68 \\
\hline G4 & 316.80 & 80.80 & 21.34 & 13.07 & 53.75 & 52.35 & 158.47 \\
\hline Averages of G3 and G4 & 321.56 & 96.18 & 15.49 & 9.01 & 45.32 & 55.96 & 183.58 \\
\hline Mle & 1185.44 & 387.50 & 40.13 & 30.13 & 221.50 & 168.75 & 648.25 \\
\hline M2 & 653.66 & 210.00 & 32.10 & 10.70 & 120.50 & 93.70 & 341.60 \\
\hline G3-Mle (54.71\%) & 715.79 & 236.54 & 23.45 & 16.36 & 120.50 & 109.02 & 407.78 \\
\hline G4-Mle (60.21\%) & 662.43 & 202.84 & 28.82 & 19.86 & 120.50 & 98.67 & 353.35 \\
\hline Average-Mle (57.33\%) & 690.39 & 220.50 & 26.01 & 18.02 & 120.50 & 104.09 & 381.88 \\
\hline
\end{tabular}
under such situation, the mixing proportion of river water at

TABLE-4

CALCULATED COMPOSITIONS OF THE MIXED WATERS $\left(\mathrm{mg} \mathrm{L}^{-1}\right)$ 

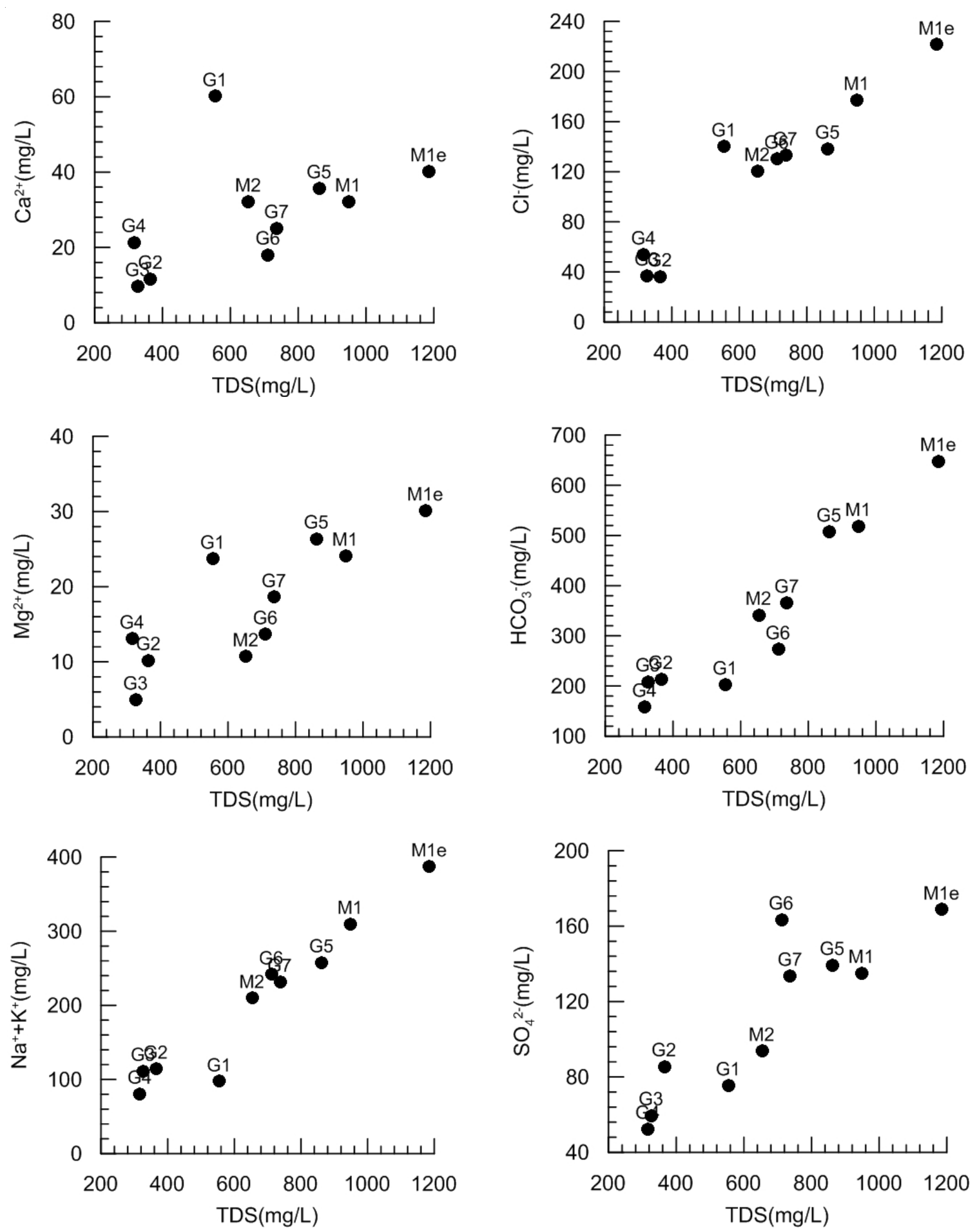

Fig. 6. Major ion concentration versus TDS for the water samples in the upper reaches of M2

M3 can't be accurately estimated because the rainwater was not sampled. However the small differences between water composition M2 and M3 suggest that the proportion of rainwater in the mixture is not large.

\section{Conclusion}

- The precipitation is less and the evaporation is extensive in the Molin river basin. The recharge of the river water is mainly by the groundwater of Luohandong formations.

- Along the flow direction of Molin river, the TDS and the concentrations of $\mathrm{Na}^{+}, \mathrm{Ca}^{2+}, \mathrm{Mg}^{2+}, \mathrm{HCO}_{3}{ }^{-}$and $\mathrm{Cl}^{-}$of river water have a decreasing trend, while the concentrations of $\mathrm{K}^{+}$ and $\mathrm{SO}_{4}{ }^{2-}$ decrease form $\mathrm{M} 1$ to $\mathrm{M} 2$ and increase from $\mathrm{M} 2$ to $\mathrm{M} 3$.

- $\mathrm{Na}^{+}$is the dominant cation and $\mathrm{HCO}_{3}{ }^{-}$is the dominant anion in the river water. The chemical types of the river water change from $\mathrm{HCO}_{3} \cdot \mathrm{Cl}-\mathrm{Na}$ in the upper and middle reaches to $\mathrm{HCO}_{3} \cdot \mathrm{SO}_{4} \cdot \mathrm{Cl}-\mathrm{Na}$ in the lower reaches.

- The isotopic composition of the Molin river water has been affected by evaporation which leads to the enrichment of stable hydrogen and oxygen isotopes of the river water.

- The composition of river water at M1 is mainly formed by the dissolution of calcite and ion exchange reactions on the 
basis of groundwater chemistry in its upper reaches. The changes of river water chemistry and the isotope composition from M1 to M2 are mainly influenced by evaporation and mixing, and the changes from M2 to M3 are mainly caused by the dilution of rain water.

\section{ACKNOWLEDGEMENTS}

The project was supported by the Special Fund for Basic Scientific Research of Central Colleges, Chang'an University (Grant No. CHD2012TD003).

\section{REFERENCES}

1. S. Li and Q. Zhang, J. Hazard. Mater., 170, 605 (2009).

2. R.J. Gibbs, Science, 170, 1088 (1970)

3. R.J. Gibbs, Geochim. Cosmochim. Acta, 36, 1061 (1972).

4. M. Hu, R.F. Stallard and J.M. Edmond, Nature, 298, 550 (1982).

5. R.F. Stallard and J.M. Edmond, J. Geophys. Res., 86, 9844 (1981).

6. R.F. Stallard and J.M. Edmond, J. Geophys. Res., 88, 9671 (1983).

7. R.F. Stallard and J.M. Edmond, J. Geophys. Res., 92, 8293 (1987).

8. M. Meybeck, Am. J. Sci., 287, 401 (1987).

9. M.M. Sarin, S. Krishnaswamy, K. Dilli, B.L.K. Somayajulu and W.S. Moore, Geochim. Cosmochim. Acta, 53, 997 (1989).

10. J. Chen, F. Wang, X. Xia and L. Zhang, Chem. Geol., 187, 231 (2002).

11. S.K. Brennan and T.K. Lowenstein, Geochim. Cosmochim. Acta, 66, 2683 (2002)

12. T.K. Dalai, S. Krishnaswami and M.M. Sarin, Geochim. Cosmochim. Acta, 66, 3397 (2002)

13. C. Neal, M. Neal, L. Hill and H. Wickham, Sci. Total Environ., 360, 254 (2006)
14. B. Chetelat, C. Liu, Z. Zhao, Q. Wang, S. Li, J. Li and B. Wang, Geochim. Cosmochim. Acta, 72, 4254 (2008).

15. H. Qian, P. Li, J. Ding, C. Yang and X. Zhang, E-J. Chem., 8, 727 (2011).

16. L. Zhang, X. Song, J. Xia, R. Yuan, Y. Zhang, X. Liu and D. Han, Appl. Geochem., 26, 293 (2011).

17. H.B. Zhang, H. Qian, P.Y. Li and J.H. Wu, Asian J. Chem., 24, 573 (2012).

18. D. Wang, F. Liu and G. Hou, North-Western Geol., 35, 167 (2002).

19. D. Wang, Z. Liu, L. Yin and J. Liu, Analysis of Groundwater Systems in Ordos Basin. In: Groundwater Resources and their Sustainable Utilization in the Ordos Basin, Shaanxi Science and Technology Press (2004).

20. Y. Xie, J. Wang and Y. Yin, Geol. Bull., 22, 819 (2003).

21. Y. Xie, J. Wang, X. Jiang, M. Li and G. Deng, Hydrogeol. Eng. Geol., 2, 11 (2005).

22. G. Hou, D. Wang and L. Yin, Structural Analysis and Exploration Directions of Groundwater System in Ordos Basin. In: Groundwater Resources and their Sustainable Utilization in the Ordos Basin, Shaanxi Science and Technology Press (2004).

23. G. Hou, X. Lin, X. Su, X. Wang and J. Liu, J. Jilin Univ. (Earth Science Edition), 36, 391 (2005).

24. Y. Sun and G. Qiao, Preliminary Analysis of Groundwater System in Ordos Cretaceous Artesan Basin. In: Groundwater Resources and their Sustainable Utilization in the Ordos Basin, Shaanxi Science and Technology Press (2004).

25. H. Craig, Science, 133, 1702 (1961).

26. J.R. Gat and R. Gonfiantini, Stable Isotope Hydrology, Deuterium and Oxygen in the Water Cycle. IAEA, Vienna, Technical Report Series, 210 (1981)

27. J.R. Gat, Ann. Rev. Earth Planet Sci., 24, 225 (1996).

28. I. Clark and P. Fritz, Environmental Isotopes in Hydrogeology. New York: Lewis (1997) 